\author{
Весна Г. ПОЛОВИНА* \\ Универзитет у Београду \\ Филолошки факултет \\ Катедра за општу лингвистику
}

\title{
ПОЈАМ ФУНКЦИЈЕ У ЛИНГВИСТИЦИ ТЕКСТА/ДИСКУРСА У ЈУЖНОСЛОВЕНСКОЈ ЛИНГВИСТИЦИ
}

\begin{abstract}
Појам функиије је често полисемичан, а у лингвистици текста односно анализи дискурса, као посебним дисциплинама, изузетно је важан. Уобичајено је да је основа његовог значења „циљ” или „намена” неког облика, исказа или дела дискурса/текста, али постоји велика варијабилност како у структурама којима се одређује нека функција, тако и у томе чему служи неки облик или појава у оквиру шире надреченичне целине. Тако се наводе, најчешће, или опште категорије мишљења и закључивања: аналогија, однос узрока и последице, контраст и сл., или неке од социјалних и прагматичких категорија: на пример, говорни чинови, ублажавање исказа, истицање и сл. Наша је намера да овај феномен и разноликост проучимо у лингвистичким радовима који се баве лингвистиком текста / анализом дискурса на јужнословенском језичком подручју пре свега, те да их упоредимо са другом лингвистичком продукцијом, како бисмо утврдили: сличности и разлике у употреби појма и термина „функција”, међусобне утицаје, као и елементе преплитања са другим доминантним лингвистичким традицијама (англо-америчком, француском и немачком релевантном литературом).

Кључне речи: функција, текстлингвистика, дискурс, славистичка традиција.
\end{abstract}

По Речнику Матице српске, функиија означава: 1. а. врщење неке радње или службе; дужност, посао, служба. - Једнога јутра кренула је госпа Настасија обучена и накинђурена као да је у функцији проводаџинице. Срем. Радован изгуби функцију берача загребачке плацовине. Матош.б. сврха, намена, ииль. 2. мат. зависна променљива величина која се мења зависно од мењања друге величине. - Кажемо ... да је опсег круга функција полумјера круга, гдје ријеч „функција” значи исто што и „зависи”. Алг. 1. 3. биол. специфичан рад органа и рад организма уопште.

У лингвистици термин и појам функиије употребљава се свакако одвајкада, баш зато што је језичка активност сврсисходна, у најопштијем смислу служи комуникацији. Али се комплексност језичких јединица, форми и структура тешко може

*polovinav@fil.bg.ac.rs 
свести на уопштену функцију, те се за сваки ниво језика, од фонологије до текста, може говорити о специфичним функцијама, улогама које они могу имати. У раду ћемо размотрити како се та разноликост прелама у светлу текстлингвистике. Иако нећемо улазити у историјат лингвистике текста, а о њему постоји довољно података у неким цитираним студијама (Beaugrand, Dressler 1981; Glovacki-Bernardi 2004; Polovina 1999; да наведемо само неке), пошто се ту ипак ради о формалном, структурном и семантичком аспекту, који сви утичу на тумачње и разумевање текста или његових делова, па и њихових функција, навешћемо на почетку два правца која носе назив функционални: прашка функционална лингвистика и системска-функционална лингвистика. Оба лингвистичка правца имају дугу традицију која опстаје иновирајући се новим сазнањима. Почећемо од утицаја прашке лингвистичке школе на текстлингвистику.

Ипак, морамо да напоменемо да овај рад не представља преглед свих релевантних текстова који се могу наћи на јужнословенским језицима. У неким случајевима није било лако доћи до литературе, а понегде је тренутно интересовање аутора преовладало. Прегледом програма студија на најважнијим универзитетима у региону, установили смо да нема филологије на којима се не предају један или више курсева из области лингвистике текста, или још чешће (а та чињеница такође је индикативна), анализа дискурса.

Функционално реченични приступ. Неоспоран је утицај прашке лингвистичке школе на словенску лингвистику. А у вези са лингвистичким проучавањем текста, још је Белић четрдесетих година написао: „Већ са многих страна чују се гласови да у граматичком представљању језичких факата треба дати посебно место читавом ланцу реченица сједињених општима значењем које представља неку синтаксичкосемантичку целину.” А то је посебно битно јер је указивао на граматичке појаве које се не сусрећу у другим граматичким формама реченица, као што су посебни типови везника, контекстуално условљених непуних реченица (в. Москальская 1981).

Један правац тог утицаја рефлектује се кроз словенска проучавања функционалне реченичне перспективе, чији су, у јужнословенским лингвистикама, чини се, најистакнутији Љубомир Поповић (1997) у Србији и Јосип Силић (1984) у Хрватској. О значају информативне рашчлањености реченице оба аутора имају сличан став. Тако Силић истиче да: „Rečenica kao jedinica govora dobiva svoj puni smisao u nadrečeničnom jedinstvu [тексту/дискурсу] kao najvišoj i najsloženijoj razini sintakse" (Silić 1984: 1). Слично томе, Поповић сматра да „При проучавању реда речи конституенте синтаксичких конструкција не треба схватити само као апстрактне делове граматичке структуре, потпуно одвојене од дате говорне ситуације и контекста. Употребљени као делови конкретне реченице, тј. реченице као основне јединице не само језика него и говора, реченични чланови поред своје граматичке добијају информативну функцију, тј. своју конкретну информативну вредност, која потиче од њихове улоге у односу на комуникативни циљ који говорник жели да оствари употребом дате реченице" (1997: 11).

Иако се код оба аутора доста помиње текст, а још више контекст, њихове најважније студије посвећене су односу између синтаксичке реченичне анализе и њене контекстуализације у тексту/говору с обзиром на основне категорије функционалне реченичне перспективе: тематско-рематско рашчлањивање реченица, редослед 
речи / реченичних конституената и однос старе и нове информације (познатог и фокуса/тежишта).

Стога, када говоре о функцијама, углавном третирају или синтаксу: „Apozicija, kao ni atribut, nije samostalna sintaktička kategorija. Ona po svojoj funkciji može biti bilo atributivne bilo predikativne naravi" (Silić 1984: 21) или семантичко-синтаксичку нарав појаве: „Aktivna participijalna konstrukcija na -1-, po svojoj funkciji, odgovara odnosnom, uzročnom, vremenskom, pogodbenom i dopusnom zavisnom dijelu" (Silić 1984: 26). Поповић можда доследније истиче ,апстрактност” када је у питању синтаксичка функција у односу на њене информативне функције: „Апстрактна (= функционално још неконкретизована) синтагма „ова чаша” могла је бити употребљена у функцији субјекта, нпр. [...] Тада би се, пошто је субјекат при граматичком распореду тематски члан, ситуациона информативна вредност датог појма и синтаксичка функција одговарајућег реченичног члана подудариле. У наведеној реченици, међутим, ради се о правом објекту, тј. реченичном члану који се по својој синтаксичкој функцији распоређује у рему" (Поповић 1997: 54). Дакле, други аутор више инсистира на апстрактности и актуелизацији, мада и хрватски аутори о томе доста пишу (поред Силића, видећемо касније у раду, о томе пише и хрватска ауторка ГловацкиБернарди).

У неким објашњењима редоследа реченичних елемената аутори се позивају и на типове текста. На пример: „[глаголи у ширем примеру] nemaju istu funkciju. Glagoli naime vise, njišu se i igraju se pripadaju egzistencijalnim, a glagol otplovio je procesualnim glagolima. Stoga se prepozicija glagola vise, njišu se i igraju se ne promatra, a prepozicija glagola otplovio je promatra kao inverzija novog. (Glagoli vise, njišu se i igraju se imaju 'statički', a glagol otplovio je 'dinamički' karakter. - 'Statičnost' glagola o kojima je riječ izlazi iz paralelnog karaktera teksta, koji je, paralelni karakter, svojstven opisu.)” (Silić 1984: 56). Тако се „статичност” као семантичко-синтаксичка категорија нашла као објашњење појаве везане за редослед реченичних конституената, и то, подвлачимо, у једном типу текста - дескриптивном. Ако ће Силић касније написати и стилистику хрватског језика, дотле се Поповић доследно држи текста само уколико он употпуњује синтаксичко-граматичка објашњења, међутим, оваква врста анализе повлачи за собом и свест о тексту, контексту, ситуацији. Тако Поповић, говорећи о једном типу одредби (месних и временских), каже да она (одредба) „ситуира и истовремено на својеврстан начин семантички везује и контекстуализује атематску реченицу одн. нетематизовану рему. Та одредба, дакле, на неки начин компензира одсуство теме као номиналног члана који везује рему. Зато при типичном распореду оваква одредба претходи реми и као уводни (= оквирни) cumуент)" (1997: 2 ). Овакви оквирни ситуенти заправо представљају типичне наративне („презентативне”) функције одредби. Отуда ове синтаксичке појаве нужно условљавају говор о „наративној функцији” реченица, јер објашњавају посебан тип конституентског распореда.

Наравно, аутори говоре и о другим „функцијама”- кохезивним (Silić 1984: 141; Поповић 1997: 152-157 - у одељку под називом: „Глобални кохезивни и деиктички значај иницијалног оквирног члана"), затим о кондензаторској функцији: исказ је потпун ,iako između njegovih komponenata nedostaju [друге неке] komponente. [...] Funkcija je takvih iskaza da skraćuju, ekonomiziraju, tekst” (Silić 1984: 89). 
Изразита функционалност у језичкој анализи овог типа условљава и даље кретање ка стилистици, те на крају Силићеве књиге налазимо редове како би ,trebalo sustavno istražiti odnose u linearnoj i paralelnoj vezi, i to na predlošku svih funkcionalnih stilova. Tek tada bismo mogli utvrditi koji su gramatički, leksički i stilistički postupci svojstveni ovom, koji onom funkcionalnom stilu na razini teksta. Time bi se utro put k onom što bismo mogli nazvati stilistikom teksta” (Silić 1984: 147).

Чини нам се да је за овај приказ јужнословенске текстлингвистике интересантан рад Ладе Бадурине: Od sintakse prema suprasintaksi i dalje. Tradicionalna gramatika ili: Zašto tekst nije imao sreće s gramatikom (i gramatika s tekstom). Ауторка далеко више инсистира на некој врсти примарности текста у функционалном смислу. Она каже: „Za tekst bismo naime mogli reći da je način funkcioniranja jezika; tekstove svakodnevno proizvodimo i/ili konzumiramo, posredstvom tekstova suočavamo se s jezikom (i materinskim i stranim)", те је издвајање реченице из њеног природног контекста условљавало недостатност традиционалне граматике и тиме је „grubo zanemarena komunikacijska bit jezika!” (Badurina 2011: 43). Не само да је то питање редоследа синтаксичких компоненти већ и питање дефиниције речи. Ауторка цитира Ј. Фирбаса да „'funkcionalni' uvijek sugerira postupak što ga čini jezični element bilo koje razine u trenutku kad je izrečen i/ili zapažen (usp. Firbas 2003: 13; usp. i Firbas 1992: 22)" (2011: 47), а новина коју су пражани увели започела је, тврди Бадурина, што је ,zanimanje jezikoslovaca napokon usmjerila (i) prema nadrečeničnom jedinstvu, tj. tekstu" (2011:48), да би се даље позвала у фусноти на докторску дисертацију Силићеву: Organizacija vezanoga teksta: Lingvističko-stilistički pristup nadrečeničnom jedinstvu hrvatskoga književnog jezika и друге његове радове након дисертације. Али те новине нису довољно промениле приступ језику. Тако се у једној фусности жали: „Takvo (prihvatljivo!) gledište u praksi (i u našoj gramatičkoj svijesti) ostaje više deklarativno no stvarno. Sintakse, u najboljemu slučaju, spominju gramatičko i obavijesno ustrojstvo, i to upravo tim redoslijedom, primarnom (i 'pravom') smatra se sintaktička (gramatička) rečenična analiza, a sve ostalo može biti samo dodatak" (2011: 50).

Померања и иновирање текстлингвистике, међутим, иде и другим правцима, па се у додиру са стилистиком, прагматиком, компјутерском лингвистиком даље развија. Осврнућемо са на функционалну стилистику и прагматички усмерену текстлингвистику.

Функционална стилистика такође рефлектује наслеђе прашке лингвистичке школе. Готово нема стилистике у којој се не помиње да је „сваки језик систем подсистема" (Silić 2006). Текст је у стилистици између језика као система и језика као остварења, по Сосиру ради се више о „лингвистици оствараја”, а не о „лингвистици сустава".

У детаљном приказу Funkcionalni stilovi hrvatskoga jezika J. Silića већ поменута ауторка, Л. Бадурина, сматра да је тек на разини текста „sinteza svega onoga što karakterizira funkcionalni stil” (Badurina 2007: 173), инсистирајући на томе да се у наведеној стилистици ради више на равни „ostvaraja” (parole код Де Сосира). Текстови су оне језичке форме којима стварно комуницирамо, а јединице других, нижих језичких нивоа су само делови текста.

Истичући тематику којом се Силић бави: редоследом синтаксичких компонената, тематско-рематској организацији, а посебно јункторима и конекторима у 
знанственом тексту, честицама, које посматра с обзиром на њихову конекторску улогу, али и модалне речи, па и друга средства која могу послужити везама унутар текста, на пример, антепонираност зависне суреченице, самостална питања, императиве, прилоге упућивачког карактера, показне замјенице, изразе типа „на почетку”, „у уводноме дијелу”, „накрају”, „напокон”, „све у свему”, „на тај начин”, „у складу с тиме" и сл., у закључку цитира још једном текстуално-фунционални став да: „Funkcionalni je stil funkcionalni stil u prvome redu po svome tekstu” (Silić 2006: 217, према Badurina 2007: 177).

Док је претходни пример стилистике произашао из утицаја прашке школе, наш други пример показује унеколико општији приступ. Под новим називом, 'вербатологијом', аутори Јелена Јовановић Симић и Радоје Симић сматрају да она представља дисциплину чији су предмет: „две перспективе: између микроистраживачких настојања лингвистичке теорије (текстлингвистичких тема) и макроплана функционалне стилистике” (Јовановић Симић, Симић 2015: 21). Даље, у закључку поглавља о нарацији кажу да је њихово интересовање за „уопште вербализацију, 'утекстовљење', или 'удискурзивање' животне збиље и људских духовних покрета у сусрету са том збиљом” (Јовановић Симић, Симић 2015: 209). У тако широко замишљеној дисциплини, а ослањајући се на руске лингвисте Виноградова, Бахтина, а посебно на савременије ауторе, Дементјеву, Валгинову и сл., истичу да су и ови аутори померили своје назоре ка „функционалном и прагматичком приступу” као основама за истраживање како се организује текст и како се различити типови текста с обзиром на њихову функцију структурирају (Јовановић Симић, Симић 2015: 97). С обзиром на пажњу коју су посветили Валгиновој, која исказне форме сврстава у функционалне групе: информативни исказ и верификативни исказ, они сматрају то најзначајнијом иновацијом, али наравно уз упитаност да ли су то „сви функционални типови, или има и других, те о каквим је овде функцијама реч” (Јовановић Симић, Симић 2015: 209).

Извесно померање у правцу других сродних дисциплина, попут прагматике, налазимо у многим радовима.

Текстуално-прагматички приступ. За разлику од текслингвистике која се делом заснива на синтаксичко-функционалним односима у оквирима синтаксе, као код Силића и Поповића, као и функционалне стилистике, постоје приступи који више нагињу текстуално-прагматским аспектима. Тако Гловацки-Бернарди (GlovackiBernandi 2004) у уводном делу књиге истиче да је битно изучавање функције и употребе језика у друштвеним односима, и то у ширем смислу људске делатности. Тако види аналогију између говора и људске делатности, радње и реченице, те је, по њој, цео језички систем заправо хијерархија функција свих језичких јединица различитих нивоа (2004: 14-15).

Функције се текста, или делова текста, повезују интенционалношћу, као и делатношћу у друштву, те на пример, каже да ,glavnom temom teksta treba smatrati onu temu koja je najbliža funkciji teksta ustanovljenoj pragmatičkom analizom”. Из тога, по ауторки, следи да „Ovisno o dominantnosti, možemo razlikovati primarno deskriptivne, narativne, eksplikativne i argumentativne strukture teksta”. Стварање различитих типова текста је условљено њиховим функцијама. То је условљено и померањем текстлингвистике са „текстне граматике” на текст као основни функционално-делатни 
језички феномен. Са тог становишта „valja ispitati konstituente - njihovu učestalost, međuodnose, gustoću i kompleksnost mreže tih odnosa, dužinu teksta, početak i kraj, njihovu funkciju u tekstu". Индикативно је да функција типова текста почива (цитира Клауса Бринкера) на илокуцијским класама, па их наводи као „оsnovu određivanja mogućih funkcija teksta i razlikuje: informativnu funkciju: tip teksta - vijesti; apelativnu funkciju: tip teksta - reklama; obligacijsku funkciju: tip teksta - ugovor; kontaktnu funkciju: tip teksta - zahvala; deklarativnu funkciju: tip teksta - testament" (Glovacki Bernandi 2004: 51). Затим се посвећује даљој разради илокуцијских чинова и језичких средстава који их остварују, као и улогама/функцијама коју заменице, деиксе уопште, форички изрази и неки други текстовни сегменти имају (рецимо, наслови приповедака).

Дискурсно-прагматички приступ. У лингвистици текста/дискурса можемо означити као специфичан приступ оних аутора који су полазили пре свега од говорног дискурса или дискурса као отелотворења прагматичких функција. У српској лингвистици значајно место заузима Свенка Савић, која је од психолингвистичких истраживања, преко наратива код деце и разговорног језика дошла до Diskurs analize (Savić 1993), у којој је посебну пажњу посветила говорној продукцији, функционисању језичких средстава у говорним чиновима са функцијом комплементрирања и извињавања, те кроз специфичне типове типова текста (анализе дискурса хомилија, конверзације преко телефона, до разговора између купца и продавца). Иако се сам термин функиија или функционално ређе употребљавају у овом приступу, јасно је из радова да се природа истраживања базира на ,језику у употреби”, па је функција исказа у дискурсу итекако заступљена. На пример, у тексту којим уводи читаоца у корпус телефонских разговора, говори о правилима за отварање и затварање разговора, средствима за идентификацију говорника у различитим ситуацијама (са познатим, па непознатим саговорницима и сл.) (Savić, Mitro 1998: 5-13).

И у нашем другом примеру прагматичке анализе дискурса, Славица Перовић бави се краћим сегментима текста, односно говорним чиновима извињења, улогом упитно негативних питања као оруђа хијерархије, чија је функција „оsnaživanja hijerarhije” (Perović 2009: 43), док индиректна питања и одговоре на њих посматра у вези са прагматичком функцијом учтивости. Поред тога, проучава и наслов и лид у новинским чланцима као посебним врстама минималног текста (на надреченичном нивоу), и то у поређењу са новинским изјавама и другим пропратним текстовима везаним за политички дискурс као текст (2009: 60), те каже да наслов и лид сумирају, функционишу као сажетак текста чланка (2009: 63).

Корпусно-текстуални приступ. Ако се лингвистика текста делимично поклопила са развојем прикупљања језичког материјала, књижевног у почетку, па потом штампаних медија, али и говорног језика, свакако је од последње деценије прошлог 20. века, стварање корпуса појединачних језика и говора добило велики замах захваљујући савременим могућностима складиштења таквог материјала. Тако се за све јужнословенске језике могу наћи одговарајући корпуси језичког материјала, а у њиховој изради, па потом и анализи, раде многи лингвисти. Таква оријентација може да се уочи у свим јужнословенским лингвистикама, а као илустрацију навешћемо два примера из региона која се баве анализом низа кратких текстова на хрватском, односно српском језику, из једноставног разлога, врло практичног - што 
су нам мање доступне објављене студије или радови који су ближи класичној „текстлингвистици” (дакле, крајње практичан разлог), а више доступне анализе језичких појава базираних на корпусу.

У Хрватској је Нада Иванетић објавила књигу Govorni činovi (1995) као универзитетски уџбеник, да би из домена прагматике прешла, у својој новијој књизи Uporabni tekstovi, на бављење врстама и класификацијама текста. Врсте текста дефинише у складу са дефиницијом Клауса Бринкера: „Tekstne vrste su konvencionalni obrasci složenih jezičnih radnji koje ujedinjuju tipična kontekstualna (situacijska), komunikacijsko-funkcionalna i strukturalna (gramatička i tematska) obilježja". Њихова функција је да „olakšava orijentaciju u konkretnoj situaciji jer pokazuje nužne i moguće korake u nastanku jedne kompleksne komunikacijske radnje, načine njihova međusobnog povezivanja i posljedice pojedinih odabranih rješenja” (Ivanetić 2003: 4), дакле бави се тиме „kako uporabni tekstovi funkcioniraju u konkretnoj situaciji, pa je logično da se temelje na prikupljenim korpusima autentičnih tekstova javne, polujavne i privatne komunikacije" (Цитати наведени према: Stolac 2005).

Занимљиво је да се ауторка бави „osmrtnicama, posljednjim pozdravima, sucut/ nekrologom, zahvalom i sjećanjem”. Иако различити текстови, они чине „funkcionalno i tematski povezanu cjelinu praštanja od mrtvih", а поједини од њих имају функцију експресивно-информативну, парципативно-експресивну итд.

Ако је „Znanje о kulturemima i o društvenoj funkciji neke tekstne vrste” (Ivanetić 2003: 179) изузетно значајно за разумевање ових текстова, онда није чудо да је и у Србији урађено, од стране лингвисте слично истраживање, али проширено поређењем три културна и текстуална обрасца. Тако Јелена Костић Томовић (2016) у раду „Obrasci tekstualizacije - jezička i kulturna uslovljenost na primeru porodičnih oglasa" такође се ослања на познатог немачког лингвисту Клауса Бринкера. И ова ауторка дефинише врсте текста на следећи начин: „Врсте текста су конвенционални обрасци за обављање сложених језичких радњи и могу се описати као типични спојеви контекстуалних (ситуативних), комуникативнофункционалних и структуралних (граматичких и тематских) својстава" (те цитира: Brinker 1992: 132) (Kostić Tomović 2016: 124).

Међутим, иако и она говори о информативној функцији огласа о догађајима у њиховом окружењу, инсистира на томе да породични огласи врше тзв. социоинтегративну функцију. Они успостављају комуникацију међу житељима одређене области, јачајући тако осећај заједништва и идентификације с непосредним окружењем, друштвеном групом и широм заједницом. На основу табеле може се видети то да је основна функција умрлица у СР Немачкој управо само обавештавање о смрти, а све преостале функције знатно заостају за њом (Kostić Tomović 2016: 144). Поредећи са Црном Гором, каже да и ту доминира једна функција, наиме обележавање помена, док све су остале функције у другом плану. У Србији је ситуација другачија него у Немачкој и Црној Гори, јер ту ниједна функција не односи уочљиво превагу. Ово су само неки од закључака компарације функција ових текстова у различитим културним срединама.

Морамо овде истаћи да је већина литературе коју сви горе наведени аутори користе углавном традиционална: цитирају се домаћи аутори и нека доминантна струја текстлингвистике из појединих земаља (пре свега немачки лингвисти), у за- 
висности од контаката аутора са другим лингвистима (професорима, колегама), као и од преферираног језика на коме се чита таква стручна и научна литература (мада у новијим написима све више доминира литература на енглеском језику).

Закључак. Иако је наш преглед и анализа употребе појма функциије у текстлингвистици сигурно ограничен избором који смо направили, указују се правци развоја, у основи, функционалног приступа језику: од оквира реченице до текста и, враћајући се појединим појавама у тексту, кроз неминовно преплитање са другим дисциплинама, прагматиком, стилистиком, корпусном лингвистиком, текстлингвистика / анализа дискурса се стално мења и модернизује и на нашим просторима, везујући се вертикално, пре свега, за „центре” науке у својој научној средини, као и

у англосаксонској, немачкој и руској, и понешто чешкој, пољској, француској средини, али не довољно и за друге лингвистичке традиције, на пример, за јужнословенски простор.

\section{Литература}

Јовановић Симић Ј. Симић Р. Вербатологија. Лингвистичке основе науке о вербализаичји света. Београд: НДСЈ, 2015.

Москальская О. И. Граматика текста. Москва: Висшая школа, 1981.

Поповић Љ. Ред речи у реченици. Београд: Друштво за српски језик и књижевност Србије, 1997.

Badurina L. „Od sintakse prema suprasintaksi i dalje (From syntax to suprasyntax and beyond)." Mićanović K. (ur.). Sintaksa hrvatskoga jezika - Književnost i kultura osamdesetih. Zbornik radova 39. seminara Zagrebačke slavističke škole, Zagreb: Zagrebačka slavistička škola, 2011: str. 43-65.

Badurina L. „Jezik i njegove službe. Funkcionalni stilovi hrvatskoga jezika, Josip Silić, (Disput, Zagreb, 2006.).”, prikazi, Fluminensia, 19 (2007) br. 1, str. 165-190.

Beaugrand R., Dressler W. Introduction into Text Linguistics. London - New York, 1981.

Brinker K. Linguistische Textanalyse. Eine Einführung in Grundbegriffe und Methoden. Berlin: Erich Schmidt Verlag, 1992.

Glovacki-Bernardi Z. O tekstu. Zagreb: Školska knjiga, 2004.

Ivanetić N. Govorni činovi. Zagreb: Zavod za lingvistiku Filozofskoga fakulteta Sveučilista u Zagrebu, 1995.

Ivanetić N. Uporabni tekstovi. Zagreb: Zavod za lingvistiku Filozofskoga fakulteta Sveučilišta u Zagrebu, 2003.

Perović S. Jezik u akciji. Podgorica: CID i ISJ, 2009.

Polovina V. Semantika i tekstlingvistika. Beograd: Čigoja, 1999.

Savić S. Diskurs analiza. Novi Sad: Filozofski fakultet, 1993.

Savić S., Mitro V. Diskurs telefonskih razgovora. Novi Sad: Filozofski fakultet, 1998.

Silić J. Funkcionalni stilovi hrvatskoga jezika. Zagreb: Disput, 2006. 
Silić J. Od rečenice do teksta. (Teoretsko-metodološke pretpostavke nadrečeničnog jedinstva). Zagreb: Sveučilišna naklada Liber, 1984.

Stolac D. „Lingvistika tekstnih vrsta, Nada Ivanetić, Uporabni tekstovi, (Zavod za lingvistiku Filozofskoga fakulteta Sveučilišta u Zagrebu, Zagreb 2003).”, prikazi, Fluminensia, 17 (2005), br. 1, str. 73-76.

Kostić Tomović J. „Obrasci tekstualizacije - jezička i kulturna uslovljenost na primeru porodičnih oglasa." U carstvu reči - jezici i kulture, Zbornik u čast prof. dr Jovanu Đukanoviću povodom 85. rođendana, Beograd: Filološki fakultet, FOCUS - Forum za interkulturnu komunikaciju, 2016: str. 122-154.

Vesna G. Polovina

THE NOTION AND USE OF FUNCTION IN SOUTH SLAVIC TEXTLINGUISTICS

Summary

Based on a number of texts, predominantly from Serbian and Croatian texlinguistic tradition, we show that a possible perspective on the trends in South Slavic texlinguistics can be established: from a strong impact that Prague school of linguistics has had on the study of texts/discourse, as shown by research into functional sentence perspective, to Systemic/Functional approach, and the interdisciplinarity that these phenomena necessarily involve, the linguistic literature moved to text types, pragmatics and stylistics of texts.

Key words: textlinguistics, discourse, South Slavic languages. 